\title{
The Application of KOMET Evaluation Technology in Teaching
}

\author{
Zheng Liu \\ No 133 of Ziqiang Rord (west),Xi'an Railway Vocational and Technical Institute, Xi'an, 710064, \\ P.R.China \\ 4663085@qq.com
}

Keywords: KOMET evaluation technology; Professional ability; Teaching application

\begin{abstract}
To a certain extent, KOMET evaluation technology promotes the reform of education and teaching in Occupation College. KOMET evaluation technology is applied to teaching; Teachers can not only have a better understanding of the characteristics of occupation education, devise the study tasks scientifically and systematically, develop the teaching that is oriented toward the working process and make scientific and reasonable evaluation and self-evaluation to the teaching effect, but also promote the school-enterprise cooperation.
\end{abstract}

\section{Introduction}

Higher vocational education aims to achieve the comprehensive development of talent.It means that the core task of higher vocational colleges is to promote the development of students 'comprehensive professional ability and improve the professional quality of students. However, it is extremely difficult to evaluate the professional ability and the professional quality of studentsscientifically.Considering the teaching practice of higher vocational education, teachers need to reform the current curriculum and teaching in order to improve the professional quality of students and to make scientific evaluation of their professional ability. KOMET(German vocational competence and professional identity assessment project) has made ambitious attempts for the reform. Up to now, it is a kind of evaluation technology, which specifically takesthe higher vocational student as the testing objects after other ability evaluation methods. Such as the Olympic skills contest,programfor international student assessment(PISA), andvocational qualification examination. It can obtain lots of datum about the quality of teaching, because KOMET evaluation technology is introduced into the process of teaching, and then there is one possibility that evaluation with evidence and quantitative datum replace the subjective judgments and guesses. KOMET is expected to be an effective method for developing professional ability and quality of students through a series of reforms[1].

\section{Build the Educational Application Mode of KOMET Evaluation Technology}

KOMET evaluation technology is designed to measure professional competence and professional quality of students, including professional identify and occupational commitment. It evaluates professional competence and quality of students of higher vocational education by establishing the model of professional competence, designing, and developing methods of evaluation. Themain method of KOMET is open test-questions questionnaire, which based on the given work tasks. The questionnaire was set upon the basis of the corresponding professional course of higher vocational education,namely the evaluation is based on the teaching contents of professional teachers. Thus, the teachers' teaching design and teaching contents have great influence on the evaluation of KOMET. Meanwhile,the competenceevaluation model of KOMET can influence the teaching design andteaching content of teachers. In contrast, the evaluating results of KOMET can directly reflect problems and defects, which existed in the relative education, the teaching designandteaching contents of teachers, teaching methods and practical teaching. Moreover, it will be record as a basis for improvement. Therefore, KOMET evaluation technology is an effective instrument which benefits to promote the reform of curriculum and teaching, analyses and improves the teaching design systematically and in-depth, and solves many problems in teaching practice. 
After evaluating the professional ability and quality of students through the KOMET evaluation technology, the evaluating results will guide the reform of education and the design of teaching contents, the improvement of methods, the solution of problems in practical teaching, reform of education and teaching and improvement of teaching practice. That can further improve the development and design of the application of KOMET evaluation technology.So getting to the next virtuous cycle of reformation and building the appliedmode of KOMET evaluation technology in teaching process is "the applied design of KOMET's evaluation technology ( teaching design)----the implement of evaluation ----the reformation of education and teaching practice ----the next applied design of KOMET's evaluation technology".

Thus, the open learning and teaching tasks couldapply the guidance of results that teachers obtain through the ability range of KOMET and implementation of evaluation indexes in the course of teaching.It can provide the solid and feasible basic for teaching practice of teachers through the standardized evaluation of KOMET and the self-assessmentof teaching activities, which also can control the teaching quality.Scientificallythat will improve the teachingquality further.

\section{Teaching Design Based on Working Process and Enterprise Production Flow}

The key point of circulation from the last application design of KOMET evaluation technology to the next application design is teaching design, whichbased on working process and enterprise production flow in accordance with evaluation bases provided by KOMET evaluation technology. Therefore, the front-line teachers should more adopt the opening learning tasks to complete teaching, and it is necessary to have a perfect teaching design as a basis for designing a good learning task that meets the requirements of ability.

Teaching Design Based on Work Process and Enterprise Production Flow. The target object of KOMET evaluation technology is students of higher vocational education, and the basic point is to give working contents. The purpose is to evaluate professional ability and quality of students. The accomplishment of KOMET depends on professional teaching including training and practice, while the accomplishment of professional teaching contents more depends on working process required by KOMET evaluation technology and teaching design of enterprise production flow.Therefore, it is a very effective approach to achieve goals of education and teaching by applying the requirements of KOMET evaluation technology or evaluation results to finish teaching design that based on working process and enterprise production flow.

Professional action capability and design ability belong to senior vocational ability in the KOMET evaluation technology. In teaching practice, it is necessary to operating the teaching design based on working process and enterprise production flow in order to promote the development of students' professional action ability and design ability. For example, taking railway transportation marketing as a given work task. The railway transportation marketing is an overall marketing activity that bases on the premise of satisfying the demand of passengers and operating around the transportation market. Therefore, marketing activities of the railway transportation are extremely complex and changeable, and the marketing process of transporting products cannot be generalized.Based on the process of working and the production of enterprise, the paper does study the working process of transportation.Marketing and which can be divided into four stage including market survey before the selling, the production marketing,the after-scaled service and the marketing management throughout the marketing activities of transportation products. And to finishthe design of the course accord to these four stages. The contents of the course include four learning areas and fifteen learning tasks.

Design of Learning Tasks. The vocational competence model of KOMET divides learning tasks into three types or levels according to students' cognitive rules: the simple tasks for beginners, the comprehensive tasks for the enhancement and the project tasks for experts. Between among levels, there is a process of systematic cognition, which is gradual and organic connected. Therefore, the learning tasks should be coherent and interrelated which form the simple learning tasks transmit to the complex holistic tasks. Scientifically designed learning tasks aim to help students to learn how to solve 
complicated problems, develop vocational skills, and ultimately achieve a learning purpose of self-orientation.

There must be some deviations between the teaching and KOMET, because they belong to two different links. Teaching be dominated by rational knowledge, and KOMET is dominated by perceptual knowledge. Students' ability largely depends on the deviation between the teaching and KOMET. The smaller deviation, the smaller ability, otherwise, the KOMET is bigger. Students' cognition of professional ability is embodied through KOMET evaluation technology and recorded by a quantified manner.The result of the assessment can be reflect the deviation more truthfully.

For improving the reform of teaching and the design of learning, additionally, the evaluation results can be used as the basis for the evaluation of students' ability and teacher's teaching method. It also provides good support for the completely learning task, students' learning demand, professional skills, and complex cognitive skills, which applied to the real enterprise-working environment.Itscharacteristicsare as follows.Firstly, "learning tasks " as the core of the course makes the completely meaningful tasks is motivation for studying. Secondly, it put emphasis on the development of students' ability rather than access to independent and fragmented knowledge.Moreover, it focuses on the comprehensive ability of students.

Problems to be noticed. Pay attention to the connection between the whole and the part. For example, the learning task of planning marketing activity for a new product transported by railway transportationhas four stages: marketanalysis, products sale,after-sales service, and marketing management. In addition, the order of traditional learning method is market analysis, products sale,after-salesservice, and marketing management. In other words, to learn products sale after market analysis splitsthe connection between them. That is why market analysis comes before product sales. The traditional teaching methods always ignore this problem, therefore, sowe should take four stages as a whole process and focus on the connection between them when we design the learning tasks of railway transportation marketing course. If there are six connections between them, then the order from easy to difficult is A,B,C,D,E, and F. Therefore, we can learn them from A to $F$, in the process of learning[2][3].

Focus on systematic development of students' holistic design ability. When students begin to learn a new course, they are not clear about the curriculum system. Thus, teachers can design more relatively simple tasks for students whonever learn about the railway transportation marketing courses before, and comprehensive tasks for students who have studied for a while. This cannot only cultivate student's ability to solve complex and comprehensive problems, but also measure the level of ability that students have achieved through evaluation method and provide references for employers.

Ideally, students should know the basic knowledge and the basic method of work, and have ability to accomplish simple tasks when they begin to learn a new course. After that, theyshould be askedto master the usage of tools they need and be able to finish comprehensive working tasks independently. The last they should continue to develop, consolidate and strengthen thecomprehensive professional ability, and have procedural ability or holistic design ability to reach the level of a proficient and even an expert. Taking the learning filed 1:pre-sale market survey of railway transportation products--task 1: environment analysis of railway transport market (setting other learning tasks in a similar idea) as the example:

Simple tasks for beginners. The primary content of learning tasks is to understand basic knowledge of the course,it only reguires students to understand the following superficial and notional basic knowledge----How about the market circumstances of railway transportation? Why must we analyze it? What perspectives of analysis are? And what methods of analysis are? Students in elementary stage should be of "conceptual ability or quality".

Comprehensive tasks for raisers. After comleted the four learning tasks, students have mastered some basic knowledge involving the analysis of transporation market sircomstance, the survvey and forecasting of market,the selection of tarket market, purchasing behavior of passengers and so on. However,the purpose of new learning tasks is that cultivates students to analyze the railway transporation market complehensively taking advantage of these knowledge, which reguires students to master the knowledge and skills of general professional tools. 
Program tasks for the proficicent. Students at the stage have finished the course, so they not only master all basic konwledge in the whole operating process of railwaytransportation marketing activity, but can use each section of content complehensive. Thus,students at the stage should have the design of intergrating marketing work. The content of tasks should involve the whole working process of railway transporation activity in which includes:the analysis of railway transportation market----the selling of railway transportation products----the managment of railway marketing and so on.It requires students to have the procedural ability or the integral design ability.

Control the complexity of learning tasks. A complicated learning tasks with comprehension and openness will improve the ability of student, although it requires that teachers must have higher ability of controlling teaching and better teaching resources, and it also requires students to have a certain independent learning ability. A simple learning task is easier to complete, but it is harder to develope the advanced ability of student, such as the work and creative ability.

Implementation of evaluation. The simple and closed task of skills training cannot lead to comprehensive ability to solve problems. Therefore, this paper will focus on the expert task of KOMET ability model-----let students complete the evaluation project, which is the planning program marketing railway transportation product. The specific steps are as follows:

Determine the objectives of evaluation. To understand the basic state of students' ability and provide effective references for students to correctly locate their ability;

It is convenient for teachers to understand the individual level of students, teach them according to their aptitude and supervise students who are not up to standard to strengthen their study.

Determine the structure of evaluation indexes:

Table 1 Evaluation index structure

\begin{tabular}{|c|c|c|c|c|c|}
\hline $\begin{array}{l}\text { Assessment } \\
\text { program }\end{array}$ & Instrument & Method & Object & Primary evaluation index & $\begin{array}{l}\text { Secondary } \\
\text { evaluation index }\end{array}$ \\
\hline \multirow{7}{*}{$\begin{array}{l}\text { Ability to } \\
\text { evaluation } \\
\text { (the } \\
\text { planning } \\
\text { program of } \\
\text { marketing } \\
\text { activity of } \\
\text { railway } \\
\text { transportati } \\
\text { on products }\end{array}$} & \multirow{7}{*}{$\begin{array}{l}\text { Teaching } \\
\text { assignment } \\
\text { text }\end{array}$} & \multirow{7}{*}{$\begin{array}{l}\text { Open } \\
\text {-ended } \\
\text { (Allow } \\
\text { reading } \\
\text { books } \\
\text { and } \\
\text { material } \\
\text { s }\end{array}$} & \multirow{7}{*}{$\begin{array}{l}\text { Railway } \\
\text { operation } \\
\text { management } \\
\text { major } \\
\text { students( sop } \\
\text { homore ) }\end{array}$} & \multirow{2}{*}{ Functional ability } & Functionality \\
\hline & & & & & Intuitiveness \\
\hline & & & & \multirow[b]{3}{*}{ The ability of work flow } & Value of using \\
\hline & & & & & Economy \\
\hline & & & & & $\begin{array}{l}\text { Orientation of work } \\
\text { and enterprises' } \\
\text { flow }\end{array}$ \\
\hline & & & & \multirow{2}{*}{$\begin{array}{l}\text { The ability of systematic } \\
\text { creativity }\end{array}$} & Social Acceptability \\
\hline & & & & & Creativity \\
\hline
\end{tabular}

Determine the score of conformance to standards. According to KOMET's design, the level of students' ability measure by the expert project-----the planning program of marketing activity of railway transportation products(120 minutes). Table 2-3 gives the score of conformance:

Table 2 Points and corresponding points of each scoring point

\begin{tabular}{|c|c|c|c|c|}
\hline $\begin{array}{l}\text { The degree of } \\
\text { conformance }\end{array}$ & $\begin{array}{l}\text { Complete } \\
\text { compliance }\end{array}$ & Most compliance & Basic compliance & Non- compliance \\
\hline Score & 3 & 2 & 1 & 0 \\
\hline
\end{tabular}

Design the form of evaluation.

.Determine evaluation staff (see appendix 1). For insure the reliability of evaluation results, the staff needs two person and should be the senior teacher of this course. 


\section{Summary and Prospect}

Introducing KOMET evaluation technology and evaluation results into the process of teaching highlights the ability of cultivating students' self-learning. The author found that it has good effects through adopting KOMET evaluation technology to evaluate students, applying the requirements and results of KOMET to the practice of teaching design and the actual situation of the class.

Achieved the required ability of railway transportation marketing course.

It is highlighted a teaching mode of students as the main body and teachers as the guidance, and improved effectively students' ability of analyzing and solving problems.

Improved students' interesting in learning and changed attitudes of study.

The design of learning tasks emphasizes the working process and the orientation of business flow. The teaching method that combines theory with practice makes students feel real situation of work, which can achieve the teaching purpose of shortening adaptive period after graduation.

Changed the single assessment mode.

Developed students' ability to apply knowledge.

However, operation KOMET evaluation technology again found that obvious problems still exist in the reform of teaching method about railway transportation marketing course. KOMET evaluation technology, it is mainly influenced by teaching time, the learning ability of students, the equipment and facilities of teaching experimental and the teaching experience of the author.The defects showthat there is a gap between the specification of learning tasks in each module and the facilities of stimulated training and the actual working process of rail transit enterprises. In the future, we need to strengthen cooperation with the marketing department of the railway bureau to improve teaching contents, to make the teaching contents of railway transportation marketing course is closer to the actual needs of railway enterprises.In addition, there have been some problems in the reform of teaching. For example, classroom management does not adapt to new requirement and some students do not adapt the new teaching methods.

The defects of the above evaluation results are the great advantages of KOMET evaluation technology applied in teaching practice. It clearly indicates the direction of the practical reform, the improvement, and the exploration of education in the future.

\section{References}

[1] Felix Rauner: Professional Ability and Evaluation of Professional Ability :KOMET Theoretical Basis and Program.( Tsinghua University Press , P.R.China ,2010,p.7,48-53,114,172-174.

[2] N .P .Jiang: Vocational and Technical Education, vol.10( 2001), p.19.

[3] H. Y. Xiao and Z. L. Li: Global Education, vol.4(2013) ,p.103. 


\section{Appendix 1}

\section{The result of the product marketing activity planning scheme evaluation of a railway company}

Task: The product marketing activity

planning of the railway company

Student number:

Judger :

Date:

\section{Fuctional ability}

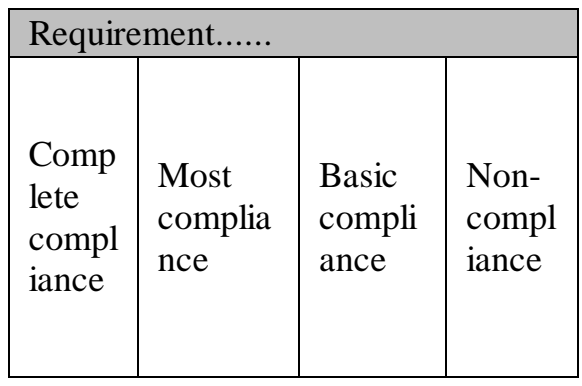

Intuitiveness

\begin{tabular}{|c|l|l|l|l|}
\hline $\mathrm{a}$ & $\begin{array}{l}\text { Whether the express of planning scheme would be accepted by } \\
\text { students? }\end{array}$ & & & \\
\hline $\mathrm{b}$ & $\begin{array}{l}\text { Whether it is proper to describe the planning scheme for the } \\
\text { professionals? }\end{array}$ & & & \\
\hline $\mathrm{c}$ & $\begin{array}{l}\text { Whether it explains the planning scheme of the tasksdirectly } \\
\text { (diagrams/drawings)? }\end{array}$ & & & \\
\hline $\mathrm{d}$ & $\begin{array}{l}\text { Whether the structure of the planning schemes and the method of } \\
\text { description are distinct? }\end{array}$ & & & \\
\hline $\mathrm{e}$ & $\begin{array}{l}\text { Whether theplanning scheme accords with with professional } \\
\text { norms? }\end{array}$ & & \\
\hline
\end{tabular}

Functionality

\begin{tabular}{|c|l|l|l|l|l|}
\hline $\mathrm{a}$ & Whether the planning scheme will meet functional demands? & & & & \\
\hline $\mathrm{b}$ & Whether the planning scheme will be operated? & & & \\
\hline $\mathrm{c}$ & Whetherthe planning scheme is scientific and professional? & & & & \\
\hline $\mathrm{d}$ & Whether it gives reasons from professional basic knowledge & & & & \\
\hline $\mathrm{e}$ & Whether theexpression of the planning schemeis correct? & & & & \\
\hline
\end{tabular}

\section{Processdural ability}

The guidance of use-in-value

\begin{tabular}{|c|l|l|l|l|l|}
\hline a & $\begin{array}{l}\text { Whether theplanning scheme will be adopted by railway } \\
\text { enterprises? }\end{array}$ & & & \\
\hline $\mathrm{b}$ & $\begin{array}{l}\text { Whether the planning scheme will develop the market of railway } \\
\text { transportation product? }\end{array}$ & & & & \\
\hline
\end{tabular}

Economy

\begin{tabular}{|c|l|l|l|l|}
\hline a & $\begin{array}{l}\text { Whether the cost will be reduced throughthe implementof } \\
\text { planning scheme? }\end{array}$ & & & \\
\hline $\mathrm{b}$ & $\begin{array}{l}\text { Whether the implement of the planning scheme will bring new } \\
\text { growth points ofmarket for railway enterprises products? }\end{array}$ & & & \\
\hline
\end{tabular}

The guidance of working process and business process

\begin{tabular}{|c|l|l|l|l|}
\hline $\mathrm{a}$ & $\begin{array}{l}\text { Whether the implement of the planning scheme will based on } \\
\text { working practice instead of textbooks? }\end{array}$ & & & \\
\hline $\mathrm{b}$ & $\begin{array}{l}\text { Whether the implementation of the plan reflect the capabilities } \\
\text { associated with typical work processes? }\end{array}$ & & & \\
\hline
\end{tabular}

\section{Conprehensive design ability}

Social Acceptability

\begin{tabular}{|c|l|l|l|l|}
\hline a & $\begin{array}{l}\text { How much dose the planning schemes take into account the } \\
\text { possibility of humanized work design and organizational design? }\end{array}$ & & & \\
\hline b & $\begin{array}{l}\text { How much dose the planning schemes take into account the impact } \\
\text { on society? }\end{array}$ & & & \\
\hline
\end{tabular}

\section{Creativity}

\begin{tabular}{|l|l|l|l|l|l|}
\hline a & Whetherthe planningscheme contains special or interesed ideas? & & & & \\
\hline b & Whetherthe planningschemeissignificants? & & & & \\
\hline c & Whetherthe planningscheme has creativitiy? & & & & \\
\hline d & Whetherthe planningscheme ultilizes fully design offered by tasks? & & & & \\
\hline
\end{tabular}

